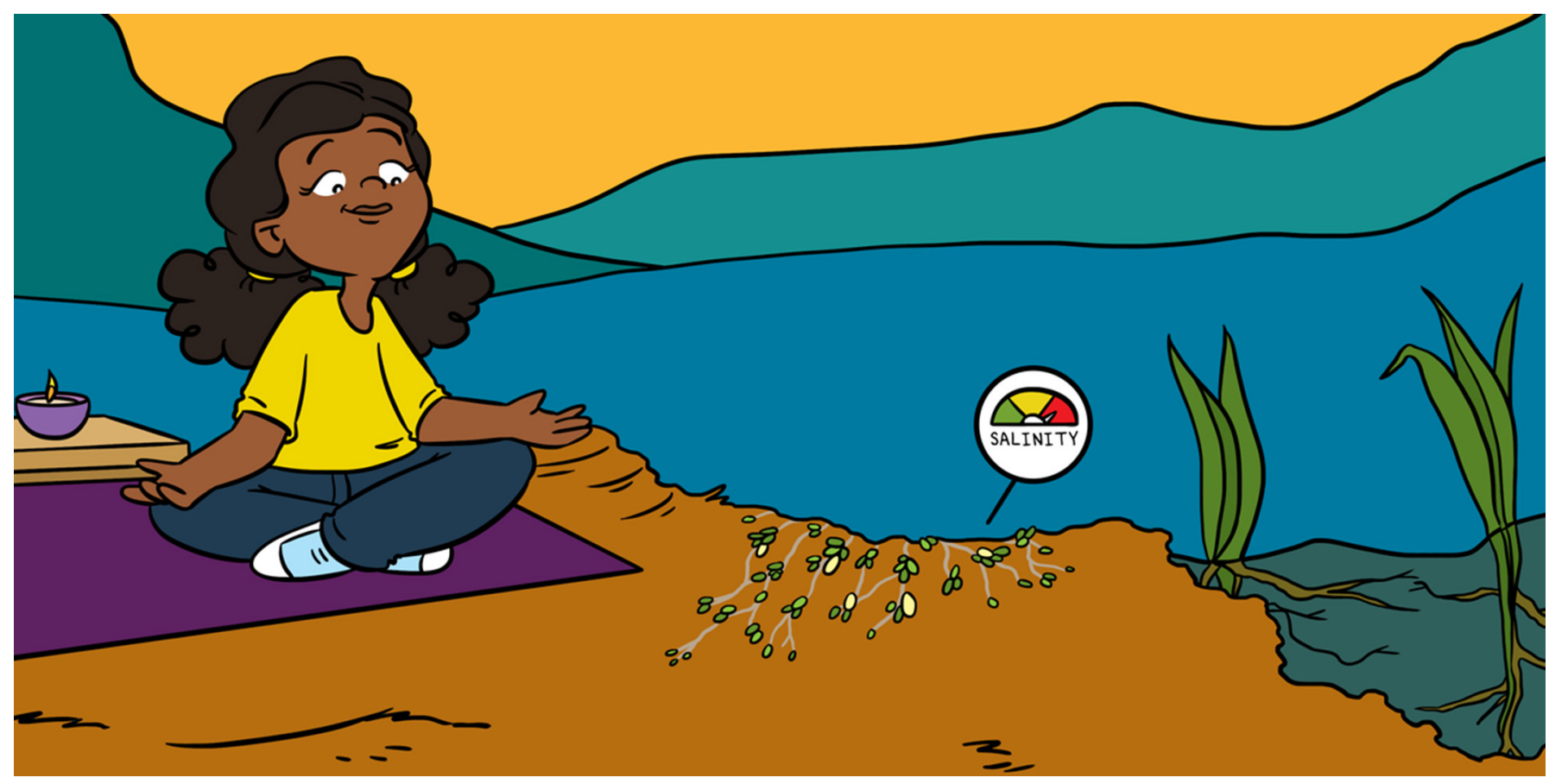

\title{
HOW WETLAND PLANTS DEAL WITH STRESS
}

\section{Taylor M. Sloey*}

Department of Biological Sciences, Old Dominion University, Norfolk, VA, United States

\section{YOUNG REVIEWER:}

KONSTANTIN

AGE: 15

\section{ESTUARY}

The mouth of a river, where freshwater from the river meets salty water from the ocean.
We all get stressed. To deal with that stress, some of us may exercise, take a bubble bath, cry, or simply leave the stressful situation. But how can you cope with stress if you are rooted in place? Plants that live in estuaries are exposed to many types of stresses from the environment, including flooding, high salt levels, low soil oxygen, and waves. Fortunately, wetland plants have developed ways to survive within these conditions, from excreting salt, to growing faster, to even breaking down cell walls to maximize air flow. Plants can tolerate different levels of stress depending on their age and species. Knowing how plants react to stress is important for our understanding of nature and for managing important environments, like wetlands! This article explores how plant species in the San Francisco Estuary react to stress and how we can use knowledge about plant stress responses to protect wetlands.

\section{LIFE IN A WETLAND-A PLANT'S PERSPECTIVE}

When you think about the San Francisco Estuary, or any wetland for that matter, what comes to mind? Perhaps a serene landscape with 
Figure 1

Wetland plants use several adaptations to respond to flooding stress, including air pockets called aerenchyma, special roots above the soil called adventitious roots, and structures that release oxygen into the soil around the roots (Image credit: IAN Image Library, 2020).

\section{STRESSORS}

Features of the environment that may create conditions that are difficult for biological organisms to survive in.

\section{ADAPTATION}

A change in a feature or process that makes an organism better suited to live in its surrounding environment.

\section{PHOTOSYNTHESIS}

The process plants use to make sugar (food) from light, water, and carbon dioxide $\left(\mathrm{CO}_{2}\right)$.

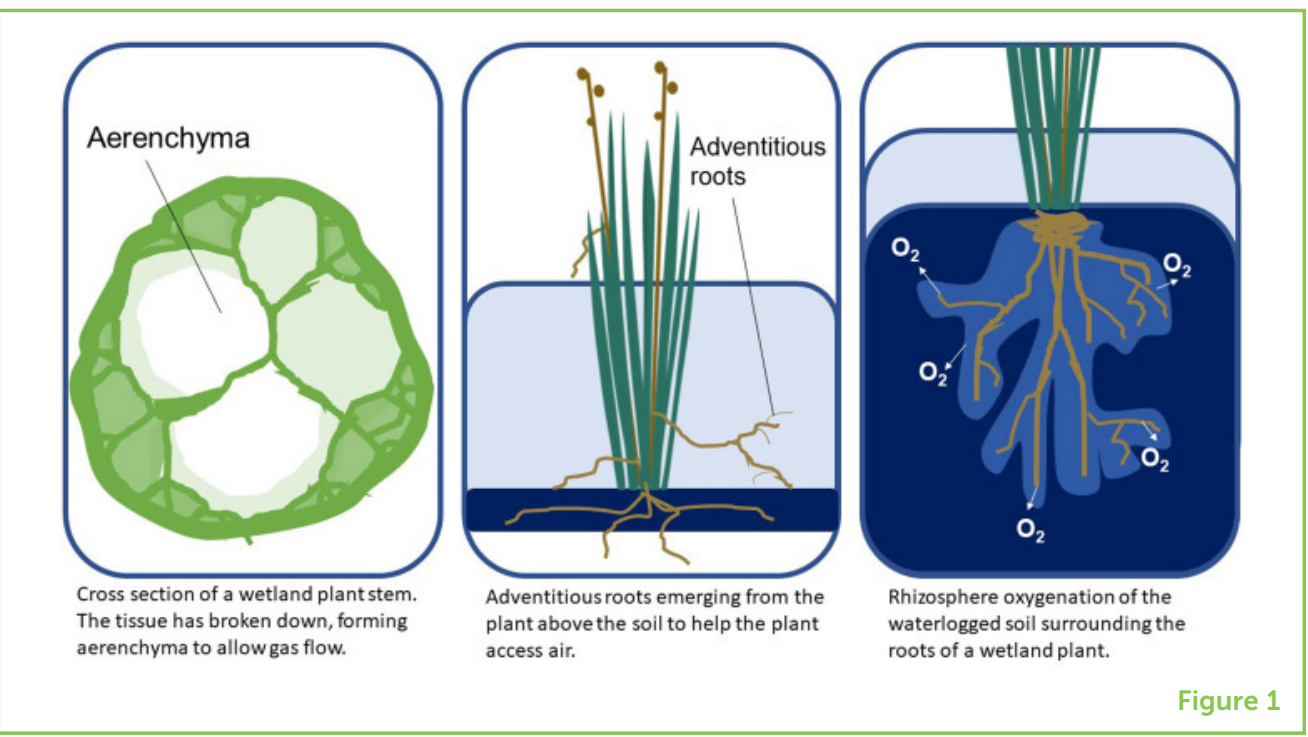

blue water trickling by, the evening songs of a red-winged blackbird, the humming of insects, and the laughter of a family fishing from a canoe. The word "stress" probably does not come to mind. However, for a plant, this scene presents several stressors that make survival and growth difficult. There are more than 391,000 species of plants on the planet [1], and although all plants need some water to survive, most of those species cannot survive being flooded for long periods of time. Flooding is only one of many stressors that a plant may have to overcome while living in an estuary; it is also stressful for plants to deal with changing amounts of salt in the water, with low levels of oxygen in the soil.

Although most plants cannot handle the stress of living in a coastal or estuarine environment, some plant species have special adaptations to help them survive these conditions; we call them wetland plants. Wetland plants all have one thing in common: they live in wet places. But there are many different species of wetland plants, including grasses, trees, and plants that live on top of or underneath the water, all of which have different adaptations to deal with stress [2]. Importantly, plant species differ in how they overcome stress and what level of stress they can handle.

\section{FLOODING STRESS-HOW FLOODED PLANTS KEEP FROM DROWNING}

Plants living in wetlands are either floating on top of the water, submerged underneath the water, or rooted in soil that is flooded at least part of the year. When flooded, plants may have limited access to the sunlight needed for growth, and their soils may have less oxygen needed for the roots. This makes survival, photosynthesis, and growth difficult, so wetland plants have evolved adaptations to cope with living in flooded places [3] (Figure 1). 


\section{AERENCHYMA}

A soft plant tissue, often found in wetland plants, that contains open spaces to increase air flow under flooded conditions.

\section{ADVENTITIOUS} ROOTS

Roots that form from a non-root part of the plant due to either normal development or in response to stress.

\section{RHIZOSPHERE} OXYGENATION

The process by which the roots of a flooded plant leak oxygen into the waterlogged soil.

\section{SALINITY}

The amount of salt dissolved into water.
One way that wetland plants may overcome flooding and low-oxygen conditions is by forming aerenchyma in their stems and root tissues. Aerenchyma are air spaces that allow the plant to move air and oxygen from above the water into its roots. These air spaces may be something the plant always had, or they may form due to a chemical reaction that breaks down cells in response to how long the plant is flooded. Therefore, a plant living in a dry place may have less aerenchyma than a plant of the same species living in a wet place [4]. Testing differences in aerenchyma between plants grown in flooded vs. non-flooded places allow us to understand how plants can respond to the stress of being flooded.

Other wetland plants deal with low-oxygen soils and flooded roots by producing roots above the soil or even above the water line. These roots, which may come out of the plant's stem, are called adventitious roots. Unlike most animals, plants can create almost any structure from almost any cell on their bodies. This is why you may occasionally see roots growing from the stem! Other wetland plants cope with flooded soil by limiting where their roots grow. For example, these plants may only produce roots at shallow soil depths, to avoid the low-oxygen conditions present deeper in the soil. Some wetland plants will use their roots to make their surroundings more comfortable. These plants use a process called rhizosphere oxygenation, in which they release oxygen from their own roots into the surrounding soil, which makes living in that soil less stressful. Finally, other plants have adapted mechanisms to escape the stress of flooding by rapidly growing their stems above the water. By keeping a portion of the stem out of the water, the plant can continue to photosynthesize and access air.

\section{SALINITY STRESS-HOW PLANTS MAKE THE BEST OF A SALTY SITUATION}

Although flooding may be a stressful component of all wetlands, coastal and estuarine wetlands have a major additional stress to deal with-salt! In estuaries, inland freshwater drains into the ocean. Fresh water is mixed with salt water and, depending on tides and seasonal weather patterns, the salinity of the water may change throughout the estuary. Most of the world's plants, and even many wetland plants, cannot survive being exposed to salt. Salt can slow plant growth and even cause death.

However, some plant species living in California's San Francisco Estuary have adapted mechanisms to avoid, exclude, or excrete salt (Figure 2). For example, pickleweed (Salicornia virginica) is a plant species that can avoid salt stress by filtering out salt and pumping it out of the roots. For other plants, like smooth cord grass (Spartina alterniflora), the leaves remove the salt that enters the plant's body [5]. Coastal plant species, like Batis maritima, put the salt into a special 
Figure 2

Wetland plants use several adaptations to deal with salt $(\mathrm{NaCl})$ stress, including preventing salt from entering the roots (exclusion), discharging salt from the leaves (excretion), or concentrating salt into a leaf which is later dropped from the plant (Image credit: IAN Image Library, 2020).

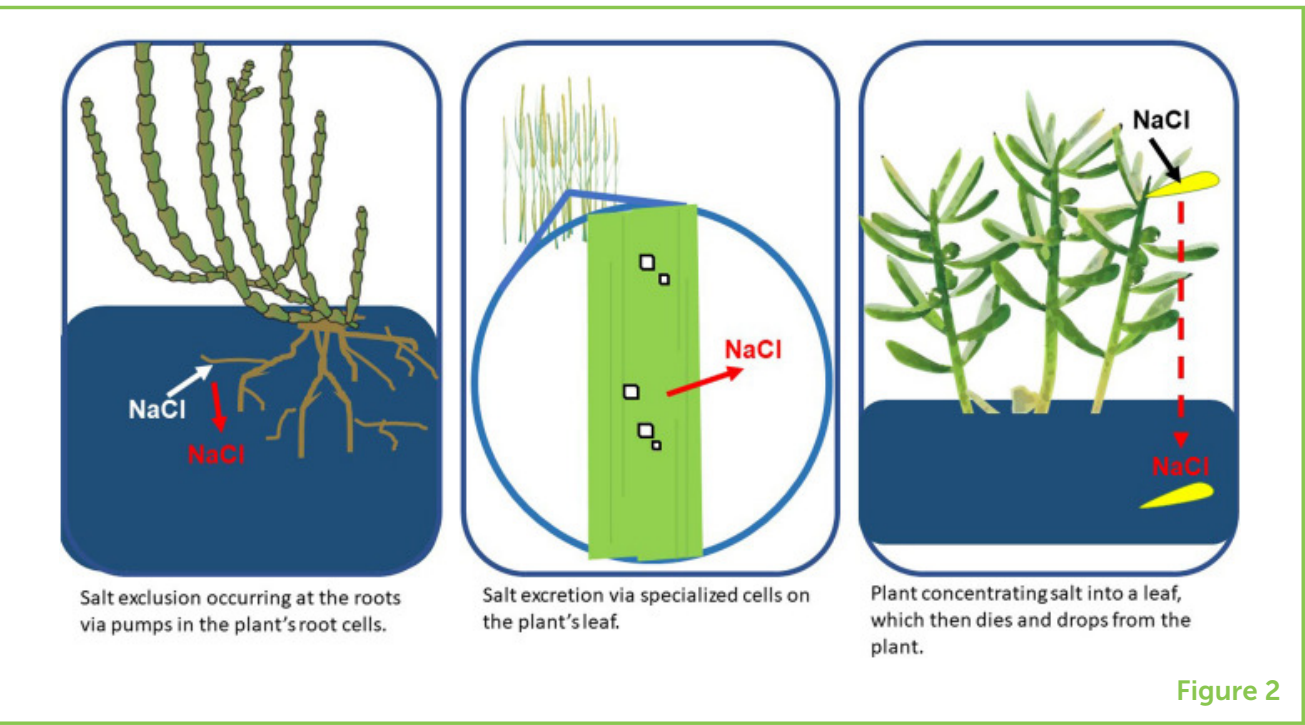

space in one of their leaves and then drop these salty leaves from the plant [6]. These are just some of the many ways that plants living in flooded and salty conditions adapt to survive a stressful life in an estuary (Figure 3).

\section{WHY DO WE NEED TO UNDERSTAND PLANT STRESS?}

Knowing what allows plants to live in wetland environments is all very interesting, but why does it matter? First, understanding interactions between species and the places they live increases our knowledge of basic science - the who, what, where, and how of planet Earth. Basic scientific knowledge is always valuable. Furthermore, by understanding how the environment affects various species, we can better understand what is going on when we see changes in the types of plant and animal species living in a particular habitat over time.

For example, sea-level rise, climate change, and other human activities can have big impacts on estuaries, particularly on flooding and salinity. When the physical conditions in the estuary change, plants and animals respond. Scientists can use their knowledge of how species react to stress to better predict how these ecosystems may look and how healthy they will be in the future [7]. Plant communities can thereby serve as an early warning of environmental changes. Responses to change will differ depending on the plant species. For example, if flooding and/or salinity increases in some areas of the estuary, some species may die back or become locally extinct, whereas other species may expand their range. It is important to preserve the plant communities in estuarine wetlands because they provide an important foundation for many other organisms that live in the estuary, like birds, fish, and people. 
Figure 3

Flood- and

salt-tolerant

adaptations in wetland

plant species that live in

the San Francisco

Estuary. Top left:

Salicornia spp. reduce

salt stress by having

succulent leaves which

are thick and contain

lots of moisture. Top

right: Batis martima

reduce salt stress by

concentrating salt into

specific leaves, which

then die, and fall off the

plant. Bottom left:

Some wetland plants,

such as

Schoenoplectus

californicus, reduce

stress from flooding by

forming aerenchyma.

The spongy tissue has spaces to enhance air flow in the plant. Bottom right: Spartina alterniflora push salt out through special cells in their leaves

(Photo credit:

BioDiversity4All.org).

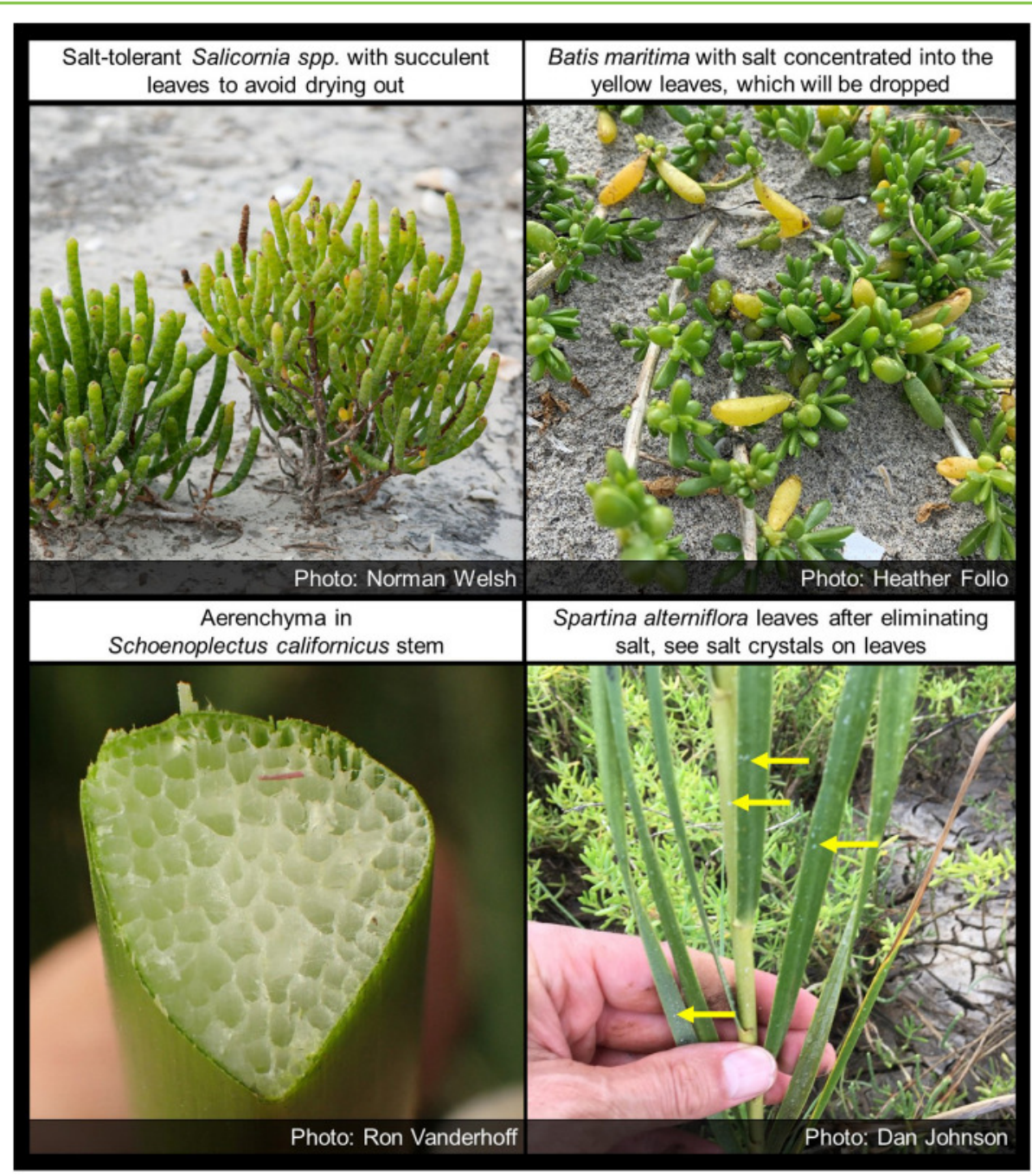

Figure 3

Scientists, conservationists, policy makers, and land managers working in estuaries all have an interest in preserving the estuary's biological diversity and ecosystem functions. Understanding plant responses to stressors like flooding and salinity can help land managers maintain the conditions needed to support that biodiversity, as well as alert these professionals to potential problems like ecosystem degradation. If land managers decide to restore parts of the estuary, they must know the physical conditions needed to support the desired plant and animal species. Wetland plant ecologists use knowledge of many plant processes to increase their understanding of wetlands and to help them make decisions for the good of the whole ecosystem.

\section{REFERENCES}

1. RBG KEW (Royal Botanic Gardens KEW). 2016. State of the World's Plants. Available online at: https://stateoftheworldsplants.org/2016/ (accessed September 16, 2020). 
2. Cronk, J. K., and Fennessy, M. S. 2016. Wetland Plants: Biology and Ecology. Boca Raton, FL: Lewis Publishers. p. 3-27.

3. Bedford, B. L., Leopold, D. J., and Gibbs, J. 2001. "Wetland ecosystems," in Encyclopedia of Biodiversity, Vol. 5, ed S. A. Levin (New York, NY: Academic Press). p. 781-804.

4. Sloey, T. M., Howard, R. J., and Hester, M. W. 2016. Response of Schoenoplectus acutus and Schoenoplectus californicus at different life-history stages to hydrologic regime. Wetlands 36:37-46. doi: 10.1007/s13157-015-0713-8

5. Levering, C. A., and Thomson, W. W. 1971. The ultrastructure of the salt gland of Spartina foliosa. Planta 97:183-96.

6. Debez, A., Saadaoui, D., Slama, I., Huchzermeyer, B., and Abdelly, C. 2010. Responses of Batis maritima plants challenged with up to two-fold seawater NaCl salinity. J. Plant Nutr. Soil Sci. 173:291-299. doi: 10.1002/jpln.200900222

7. Watson, E. B., and Byrne, R. 2009. Abundance and diversity of tidal marsh plants along the salinity gradient of the San Francisco Estuary: implications for global change ecology. Plant Ecol. 205:113. doi: 10.1007/s11258-009-9602-7

SUBMITTED: 29 September 2020; ACCEPTED: 29 July 2021;

PUBLISHED ONLINE: 25 August 2021.

EDITED BY: Pedro Morais, University of Algarve, Portugal

CITATION: Sloey TM (2021) How Wetland Plants Deal With Stress. Front. Young Minds 9:611887. doi: 10.3389/frym.2021.611887

CONFLICT OF INTEREST: The author declares that the research was conducted in the absence of any commercial or financial relationships that could be construed as a potential conflict of interest.

COPYRIGHT () 2021 Sloey. This is an open-access article distributed under the terms of the Creative Commons Attribution License (CC BY). The use, distribution or reproduction in other forums is permitted, provided the original author(s) and the copyright owner(s) are credited and that the original publication in this journal is cited, in accordance with accepted academic practice. No use, distribution or reproduction is permitted which does not comply with these terms.

\section{YOUNG REVIEWER}

\section{KONSTANTIN, AGE: 15}

Hi I am Konstantin, your nearby Young Mind! I am from Rousse, Bulgaria and since I was little I had questions like: what is the point in recycling etc. Now, as an adolescent, I really got into ecology and decided to help bring awareness of some of the problems in our world has like the air pollution, species extinction, and deforestation. If I, an ordinary student, can make a difference you can too-so what are you waiting for my young reader! 


\section{AUTHOR}

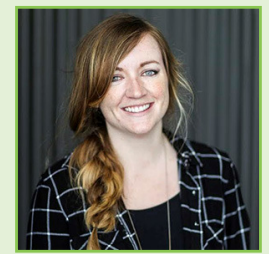

\section{TAYLOR M. SLOEY}

I am an assistant professor at Old Dominion University in Virginia. I teach classes in plant ecology, marine ecology, and plant physiology. I also lead a research lab that focuses on understanding how wetland plants and ecosystems respond to change. The goal of this type of research is to provide information to help conserve, restore, and manage wetland ecosystems successfully. My favorite part of being an environmental scientist is getting to work outdoors and problem solve with the help of other experts in my field. Learn more about my research at www.taylorsloey.weebly.com. *tsloey@odu.edu 